he reported the phenomenon of verbal transformation (reviewed by Warren, Psychol. Bull., "'0, 261; 1968) in which repetition of a single word on a tape loop gave the hearer the impression that the word altered its apparent sound. Throughout a series of a few hundred repetitions the heard sound was reported to change successively into different words. A typical series of transformations heard by a subject listening to the word "tress" repeated continually for 3 min (with the subject reporting whenever a change in apparent sound occurred) was "stress, dress, stress, dress, Jewish, Joyce, dress, Jewess, Jewish, dress, floris, florist, Joyce, dress, stress, dress, purse". An explanation for this is that unaided by context and possibly encouraged by neural adaptation, perceptions break away from the sounds usually associated with a particular physical stimulus.

The second of Warren's illusions (Science, 164, 586; 1969) should more properly be called a confusion. It turns out to be impossible to assign a correct ordering to four sounds, a high tone $(1,000 \mathrm{~Hz})$, a hiss, a low tone $(796 \mathrm{~Hz})$, and a buzz, each lasting for $200 \mathrm{~ms}$ and played repeatedly in the same order. Four spoken digits repeated at the same rate can easily be ordered even when all transitional cues such as usually occur between fluent speech sounds are absent. When listening to the cycle of sounds there is no difficulty in identifying each sound; it is the ordering that is impossible; a subject understands speech sounds which have an average duration of $70 \mathrm{~ms}$ and music can be repeated by musical subjects with notes occurring as fast as $20 / \mathrm{s}$.

These three demonstrations indicate a surprising flexibility of the mechanisms of auditory pereeption. Powerful reconstructive processes may partly account for the ability to understand speech even in the midst of other distracting noises, and for tolerance of the very different accents and sounds produced by different speakers. Warren has shown that speech perception is not a matter of guessing what might have been said. The reconstructive process gives some information about the timing of irrelevant sounds and, aided by context, yields direct impressions of coherent speech.

\section{LAND MANAGEMENT}

\section{Conservation on the Farm}

\section{from a Correspondent}

A meeting held at Monks Wood Experimental Station on February 19 and 20 should have forged contacts which will prevent future instances of two government bodies, both concerned with the countryside, giving contrary advice. The topic was land management for agriculture and conservation, and it brought together members of the Nature Conservancy and the Agricultural Land Service (ALS) of the Ministry of Agriculture, Fisheries and Food, as well as representatives of the Forestry and Countryside Commissions.

The ALS is the body which can most affect the farming pattern of England and Wales. Its officers advise farmers on all problems of estate management. Equally important they are closely concerned with the administration of the various grant and subsidy schemes which greatly influence the way farming is done, particularly in the less productive areas of Britain. The ALS is sometimes blamed by conservationists for many allegedly undesirable farming practices, including the destruction of hedgerows, factory farming of livestock and the massive use of fertilizers which pollute inland waters. Farmers, of course, complain that conservationists pay too little attention to the economics of agriculture.

The principal task facing the participants was to discover whether efficient farming need harm Britain's native flora and fauna. Because nature reserves only cover a fraction of 1 per cent of the area of lowland England, most wild plants and animals, if they are not to become extinct, must continue to be found on farm land.

There was much common ground, partly no doubt because so many members of the ALS are essentially countrymen. It had to be agreed that in many lowland areas productivity must continue to have priority, and that changes such as the removal of manypossibly most-hedgerows were inevitable. Only when farmers are keen game preservers will they retain all the cover the conservationists would desire. Mr P. J. Huguet (ALS) and Dr M. Hooper (Monks Wood Experimental Station) agreed that nevertheless even on the most intensive farms there are areas which may be set aside for the benefit of wildlife if suitable advice on their location is available. Mr J. B. Rundle (ALS) pointed out that in mountain and upland Britain farming is partly maintained for social reasons, for the subsidies might be spent more profitably (in terms of food production) in the lowlands. Here the conservationists are quite as keen as the agriculturalists that the present farming pattern should continue. Mr I. Nicholson (Nature Conservancy, Scotland) explained that controlled grazing often improves the wildlife interest.

Not all differences of approach can be resolved easily. Water pollution or eutrophication from farm wastes which cannot be economically used as manure will continue to be a problem, and so will the chemical fertilizers in the run-off from arable land, as Mr K. B. C. Jones (ALS) pointed out. Here the ALS and the National Agricultural Advisory Service may still have to give advice which they know may not be in the best interests of conservation. The only solution, said Dr K. Mellanby (Monks Wood Experimental Station), would be a change in government policy to support the use of organic manures with subsidies, something which may happen if present practices are shown to cause the deterioration in British soils which is alleged to occur in parts of North America.

The meeting revealed that clearly the ALS and the Nature Conservancy can often have an agreed policy. Where this is impossible, close collaboration can often prevent much of the damage which would otherwise occur.

\section{ANTIBIOTICS}

\section{Sense and Sensilivity}

\section{from our Molecular Biology Correspondent}

A NEW group of articles concerned with the mode of action of antibiotics of different kinds in blocking protein synthesis follows hard on the work I discussed last week. New light on the site of streptomycin action 